\title{
Web-Based Expert System Application for Diagnosing Dental and Oral Diseases
}

\author{
Budi Kurniawan
}

Teknik Informatika Fakultas Sains dan Teknologi, Universitas Islam Negeri Syarif Hidayatullah, Jakarta

\begin{tabular}{|c|c|}
\hline Article Info & ABSTRACT \\
\hline Article history: & \multirow{6}{*}{$\begin{array}{l}\text { Controlling the amount of inventory value is not an easy thing for } \\
\text { Computers in the current era of globalization are a major need in } \\
\text { supporting human work. One of the branches of computer science that } \\
\text { is widely used by humans to help work is the formation of an expert } \\
\text { system which is one of the sub-fields of artificial intelligence [1]. One of } \\
\text { the uses of expert systems is in the field of dentistry. It is proven by the } \\
\text { emergence of Nyoman Kusuma Wardna's research entitled designing } \\
\text { an expert system for diagnosing oral and dental diseases using the } \\
\text { CLIPS programming language which was published at the National } \\
\text { Seminar on Information Technology Applications held at Gajah Mada } \\
\text { University, Yogyakarta } 21 \text { June } 2008 \text {. This application appears with an } \\
\text { interface in the form of closed questions about the symptoms felt by } \\
\text { the user so that it does not maximize the diagnostic results obtained. } \\
\text { This expert system is also a development of Bambang Suyono's } \\
\text { research (National Seminar on Informatics UPN Yogyakarta } 22 \text { May } \\
\text { 2010) which has a deficiency in using the depth first search method so } \\
\text { that it is unable to display two or more solutions [3], whereas in } \\
\text { diagnosing a disease sometimes a doctor determines differential } \\
\text { diagnosis. This is what prompted the author to develop the application } \\
\text { system by correcting all existing deficiencies. The method used in this } \\
\text { research is Extreme Programming (XP) which is part of the AGILE } \\
\text { method [7], consisting of five stages, namely, Planning, Design, Coding, } \\
\text { Test and release. }\end{array}$} \\
\hline $\begin{array}{l}\text { Received: } 20 / 01 / 2021 \\
\text { Revised: 03/02/2021 } \\
\text { Accepted: } 28 / 02 / 2021 \\
\text { Available online 30/03/2021 }\end{array}$ & \\
\hline Keywords: & \\
\hline Extreme Programming, & \\
\hline Expert system, & \\
\hline Dental and Oral Disease & \\
\hline
\end{tabular}

This is an open access article under the CC BY-NC license.

\section{Corresponding Author:}

Budi Kurniawan,

Teknik Informatika Fakultas Sains dan Teknologi,

Universitas Islam Negeri Syarif Hidayatullah, Jakarta

Email: kurniawan@gmail.com

\section{Introduction}

Computers in the current era of globalization are a major need in supporting human work. One branch of computer science that is widely used by humans to help work is the formation of an expert system which is one of the sub-fields of artificial intelligence [1]. One of the uses of expert systems is in the field of lightening the guise. This is evidenced by the emergence of I Nyoman Kusuma Wardana's research entitled designing an expert system for diagnosing oral and dental diseases using the CLIPS programming language which was published at the National Seminar on Information Technology Applications held at Gajah Mada University, Yogyakarta, 21 June 2008. This application appears with an interface in the form of questions- closed questions about the symptoms felt by the user so that they do not maximize the diagnostic results obtained. This expert system is also a development of Bambang Suyono's research (National Seminar on Informatics UPN Yogyakarta 22 May 2010) which has a 
deficiency in using the depth first search method so that it is unable to display two or more solutions [3], whereas in diagnosing a disease sometimes a doctor determines differential diagnosis. This is what prompted the author to develop the application system by fixing all existing deficiencies.

The method used in this research is Extreme Programming (XP) which is part of the AGILE method [7], consisting of five stages, namely, Planning, Design, Coding, Test and release [8]. This research uses PHP version 5.3.5 software as programming language, MYSQL version 5.0.7 as database and both are contained in one localhost XAMPP package version 1.7.4, while the design of this application uses Microsoft OfficeFrontPage2003. The operating system used by the author is Microsoft Windows Vista and a Personal Computer (PC) with specifications, Intel Pentium DualCore processor, $1 \mathrm{~GB}$ RAM and 160GB hard drive. The advantage of this expert system from the previous system is that it covers a wider range of dental and oral disease diagnoses, the display is more interactive and able to determine the differential diagnosis of the closeness of the symptoms that accompany dental and oral diseases. One of the uses of the expert system is in the field of medicine or health. Implementation of expert systems in the world of medicine or health can be in the form of disease diagnosis, health care consultations to providing suggestions for determining solutions from the results of existing diagnoses.

Health is indeed an expensive item for humans, therefore it takes personal sensitivity to maintain it. One of the organs of the body that is often neglected to take care of is the teeth and mouth. Initer evidence from the Data from the Director General of Medical Services (2001) which shows that dental and oral diseases are among the top ten ranking diseases in Indonesia (Saragih, 2009:1). Based on a survey conducted by the Indonesian Dental Health Foundation (2003) on children, it showed that $70 \%$ of children suffered from dental caries and gingi vitis (gum inflammation), while $73 \%$ of adults suffered from dental caries. Meanwhile, based on the results of the household health survey (SKRT) in 2004 , as many as $90.05 \%$ of the Indonesian population have dental and oral health problems (Saragih, 2009:2). This figure also increased according to the research results of Dr. Herniyawati, Mkes in 2007 which showed as many as 72 percent of the Indonesian population experienced cavities (Hamsafir, 2010). The design of this expert system will be made web-based through php media with a database using mysql contained in the XAMPP package. The design of this expert system is built using reasoning that starts from the facts first to test the truth of the hypothesis called Forward Chaining and the design of this expert system is explained through a rule base which is a rule consisting of two parts, namely conditions and conclusions, knowledge base which is the core of the expert system program, the working inference engine. The design of this expert system will be made web-based through php media with a database using mysql contained in the XAMPP package. The design of this expert system is built using reasoning that starts from the facts first to test the truth of the hypothesis called Forward Chaining and the design of this expert system is explained through a rule base which is a rule consisting of two parts, namely conditions and conclusions, knowledge base which is the core of the expert system program, the working inference engine. The design of this expert system will be made web-based through php media with a database using mysql contained in the XAMPP package. The design of this expert system is built using reasoning that starts from the facts first to test the truth of the hypothesis called Forward Chaining and the design of this expert system is explained through a rule base which is a rule consisting of two parts, namely conditions and conclusions, knowledge base which is the core of the expert system program, the working inference engine.

\section{Method}

\subsection{Data collection}

a. Interview

Interviews were conducted by question and answer with related parties (in this case dentists) to obtain the information needed regarding problems and things needed in the process of making and developing applications.

b. Literature review 
The next stage of data collection in this research is through literature study by collecting data and information from books, websites and journals related to the subject of this research. The sources that the author uses consist of 19 (twenty) books, 6 (six) ebooks, and 8 (eight) articles sourced from websites. The book titles that the author uses as a reference are Introduction to Computers, Basic Concepts of Expert Systems, Medical Dictionary, Agile Software Construction, and more can be seen in the bibliography.

\section{c. Study of literature}

Literature study is intended as a comparison of authors in developing applications that are built. This literature study was carried out by collecting data from the thesis or journals of other people's research results that were in accordance with this research.

\subsection{Forward Chaining Method Analysis}

\section{a. Forward Chaining Reasoning Technique}

The reasoning technique (inference) used to reach conclusions that fit the needs. The inference mechanism for diagnosing dental and oral diseases is using the Forward Chaining technique (forward reasoning) which starts the search from a set of data to a conclusion.

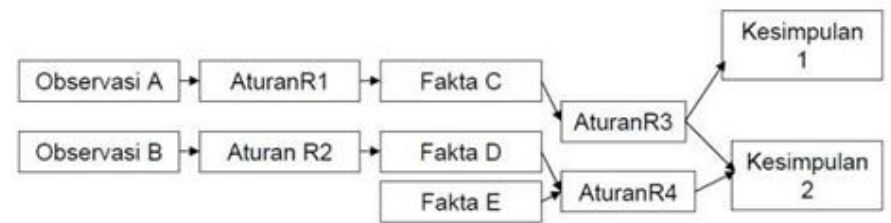

Figure 1.Forward Chaining Pattern

\section{b. Backward Chaining Reasoning Technique}

Backward reasoning technique or backward reasoning is a goal-driven approach (Arhami, 2005: 19). This reasoning is also commonly called top-down reasoning, namely reasoning that starts from the highest level to build a hypothesis, down to the lowest level of facts that can support the hypothesis. It can also be said that the backward chaining shows the facts that are used to support the hypothesis.

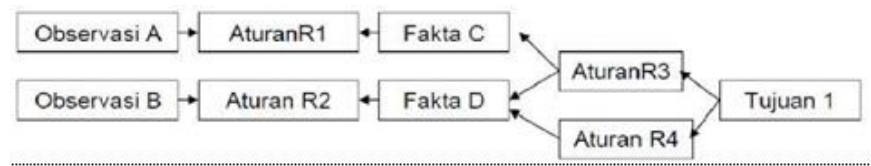

Figure 2. Backward Chaining Pattern

\section{Results and Discussion}

There are three types of search patterns that can be used, namely depth-firstsearch, breadthfirstsearch and bestfirstsearch.

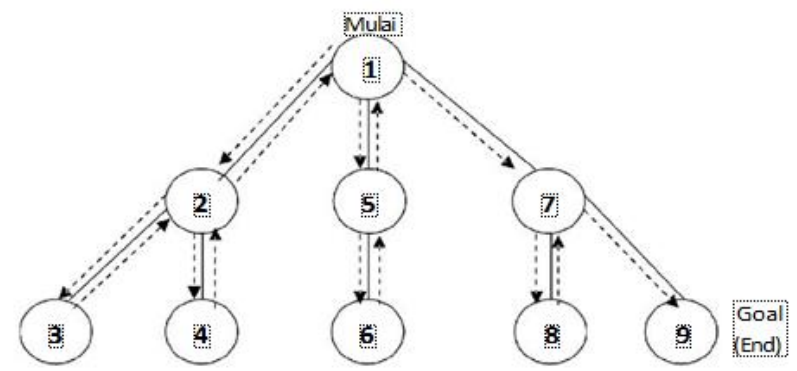

Figure 3. Depth-First Search Pattern 


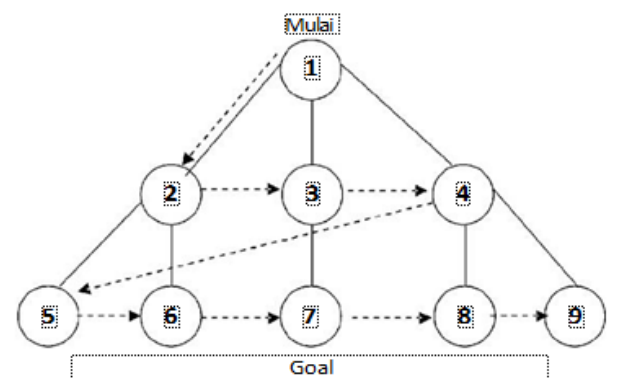

Figure 4. Breadth-First Search Patterns

Knowledge improvement is an important component of the expert system, so that the program is able to analyze the causes of its success and failure. This is the same as the character of an expert who has the ability to analyze and improve performance as well as the ability to learn from his performance. Knowledge representation is a combination of systems based on two elements, namely data structures and interpretation of procedures for using knowledge in storing data structures (Arhami, 2005:29). In an expert system, the knowledge that has been described is represented in a form that can be processed by a computer.

\section{Conclusion}

Based on the research that has been carried out, the following conclusions can be drawn: The current system makes it easier for users to carry out the consultation process, because the symptom questions asked are only related to the disease being experienced. This root system also makes it easier for admins to update the rule base, because there is a simple rulebase edit page that can be used to add, update and remove diseases.

\section{Reference}

Asiyah, S., 2005, Expert System for Diagnosing Dental Diseases, Final Project of S1 Computer Science, Faculty of Mathematics and Natural Sciences, Gadjah Mada University, Yogyakarta.

Cramwinckel, AB, 1995, Food and Dental Diseases.

Dian Retno Sawitri, 2002, Expert system based on logic programming for livestock selection simulation, Thesis, UGM, Yogyakarta.

Giarratano, J. \& Gary R., 1994, Expert Systems Principles and Programming, PWS Publishing Company, Boston.

Handayanil, Tole, 2008, Expert System for Diagnosis of ENT Diseases Web-based with "e2gLite Expert System Shell, Journal of Industrial Technology Vol. XII No.1 January 2008:19-26.

Kusuma dewi, S., 2003, Artificial Intelligence (Techniques and Applications), Graha Ilmu, Yogyakarta.

Mutaqin, 2002, Implementation of an Expert System in the Medical World: A Development of a Dental and Oral Health Diagnosis System, Thesis, UGM, Yogyakarta.

Natalia, DA, 2006, Development of an Expert System on Mobile Devices with WML and PHP for Lung Diseases in Children, Final Project of D3 Information Technology at the Electronics Polytechnic Institute of Technology Sepuluh Nopember, Surabaya.

Nurmala, E., 2007, Application of Expert System for Diagnosing Periradicular Tissue Disease in Teeth, Final Project of S1 Computer Science, Faculty of Mathematics and Natural Sciences, Gadjah Mada University, Yogyakarta.

Pressman, Roger, 2002, Software Engineering Practitioner Approach, Andi Offset, Yogyakarta.

Turban, Ephraim, 1995, Decision Support Systems and Expert Systems, 4 thed., Prentice-Hall, Inc., New Jersey, pp472-679

Widayanti Ayu A, 2009, Expert System for Diagnosis of Dental Diseases Based on WAP, Thesis of the Department of Informatics UPN "Veteran" Yogyakarta

Yuwono Bambang, 2008, Expert System for Diagnosis of Chicken Diseases Caused by Viruses, Jurnal

"Telematics" ISSN:1829-667 X, Vol.3 No.1, July 2008

Yuwono Bambang, Fauziah Y, Yenny, 2008, Web-Based Expert System to Identify Types and Diseases of Roses, Proceedings of Semnasif 2008, Department of Informatics UPN “Veteran” Yogyakarta, May 2008, ISSN: 1979 2328. 